\title{
An Analysis of Students' Higher-Order Thinking Skills for the Learning Topics of Biology during the Covid-19 Pandemic
}

\author{
$1^{\text {st }}$ Citty Asia Nst ${ }^{1}, 2^{\text {nd }}$ Hasruddin $^{2}, 3^{\text {rd }}$ Idramsa $^{3}$ \\ \{cittyasia11@gmail.com ${ }^{1}$ \} \\ Master's Degree of Biology Education, Universitas Negeri Medan, Medan, North Sumatera ${ }^{1,2,3}$

\begin{abstract}
The aims of this study were to: (1) determine the students' higher-order thinking skills for the learning topics of Biology during the Covid-19, and (2) determine the students' learning processes during the Covid-19 pandemic at SMA Negeri 4 Medan. This study applied descriptive quantitative with 175 students as samples by purposive sampling from grade eleven (XI-MIA) at SMA Negeri 4 Medan. The data of higher-order thinking skills used 10 essay questions as test instrument and questionnaires of the learning process during Covid-19 as many as 20 questions. The results showed that students' higher-order thinking skills obtained the score of 27.2 with the low category as well as students' learning processes obtained the score of 33.18 with the poor category.
\end{abstract}

Keywords: Higher-Order Thinking Skills, online learning, Covid-19 Pandemic.

\section{Introduction}

The current situation forces students to study at home because face-to-face learning is abolished as an effort to prevent the transmission and spread of Covid-19 (Coronavirus Disease). This has an impact on activities including teaching and learning activities where they are eventually carried out through distance learning. According to Imaniah \& Bariah [1], online learning is a form of delivering conventional learning that is poured into digital format via the internet. Online learning is considered to be the only medium for delivering material between teachers and students during the emergency of Covid-19 pandemic. The implementation of online learning requires the support of mobile devices such as smartphones [2]. Students only learn from home through online classes, then the teacher explains giving material through the Whatsapp group and students work on assignments independently at their respective homes.

This makes students lazy and difficult to learn because of circumstances that require them to study and do assignments independently, and the teacher observes from afar through the tasks that have been conducted by students. The current situation makes it difficult for students to understand the concepts given, especially biology material. Students' higher-order thinking skills need to be improved during the Covid-19 pandemic, because the current situation requires students to be independent, study at home, and understand their own material.

According to Hasruddin [3] during the learning process, students use thinking skills to achieve learning goals. The ability to think can be raised from the information stored in one's memory. Thinking ability can be categorized into two parts; lower-order thinking and higher- 
order thinking skills. In Bloom's taxonomy, analyzing, evaluating, and creating are included in higher-order thinking skills. Thus, higher-order thinking skills can support students' academic achievement.

In the 2013 curriculum, students are required to be more critical and creative to train students' higher-order thinking skills. The main characteristics of higher-order thinking skills are critical and creative. This is in accordance with Hasruddin's recent study [4] that critical or higher-order thinking skills are things that need to be done so that students can observe the problems that are present. Furthermore, it is equivalent to Ahmad's [5] that higher-order thinking skills consist of the ability to think logically, critically, systematically, analytically, creatively, productively, reasoning, connection, communication, and problem solving. Higherorder thinking skill is also a thinking ability that not only requires the ability to remember, but requires other higher abilities.

Based on the results of a preliminary study conducted by distributing questionnaires at SMA Negeri 4 Medan, 69\% of students expressed their opinions about the difficulty of biology learning materials. Around 73\% stated that the teaching and learning activities of biology that had taken place so far only took notes and worked on questions. It was unfortunate that learning biology was only limited to doing problems, even though around $86 \%$ of students wanted a way of learning biology with face-to-face demonstrations and practicals. Then about $74 \%$ stated that the difficulty experienced when learning biology was rote memorizing. This has led to a change in learning during the Covid-19 pandemic. Where face-to-face learning becomes online learning that suddenly occurs, creates obstacles experienced by teachers when carrying out online learning, one of which is the approach in the learning process. So that they do not understand biological material that involves a higher order thinking ability approach when online learning takes place.

In the 2013 curriculum, science learning in high school must have the goal of achieving graduate competence by improving and balancing soft skills and hard skills which include aspects of attitude, skills and knowledge competencies. All these processes lead to aspects that exist, especially in higher-order thinking skills. Therefore, with an approach to higher-order thinking skills, the success of teachers in presenting biology learning materials can facilitate students to achieve the expected competencies.

\section{Method}

This study was conducted at SMA Negeri 4 Medan from December 2020 to March 2021. The population was all students of grade eleven (XI-MIA) consisting of 10 classes with a total of 323 students. In determining the sample using the Krejcie \& Morgan table with a sample of 175 students. Random sampling was applied for the sampling technique by means of a lottery. This study applied descriptive quantitative method. The data of higher-order thinking skills used 10 essay questions as test instrument and questionnaires of the learning process during Covid-19 as many as 20 questions. Higher-order thinking tests were used to measure changes in students' abilities as a result of their higher-order thinking skills in studying the topics of Biology. After participating the learning activities in the third semester, the main topics were all about the structure/function of plant tissues, human locomotor and circulatory systems. The 
instruments were arranged in advance to develop the grids including the components of analyzing, evaluating and creating. The higher-order thinking test consists of 4 answer choices; Score $4=$ very good answer; Score $3=\operatorname{good}$ answer; Score $2=$ adequate answer; Score $1=$ less answer; and Score $0=$ no answer.

\section{Result and Discussion}

\subsection{Students' Higher-Order Thinking Skills (HOTS)}

3.1.1 Results of Students' HOTS on the Topic of Plant Tissues. From the results of students' HOTS in plant tissues during the Covid-19 pandemic at SMA Negeri 4 Medan, the data recapitulation as presented in Table 1 .

Table 1. Students' HOTS on the topic of plant tissues,

\begin{tabular}{cccccccccccccc}
\hline No. & Aspect & XI-1 & XI-2 & XI-3 & XI-4 & XI-5 & XI-6 & XI-7 & XI-8 & XI-9 & XI-10 & Mean & Category \\
\hline 1. & C4 & 26.47 & 25.10 & 24.07 & 25.19 & 25.37 & 25.93 & 26.67 & 24.63 & 25.29 & 23.92 & 25.26 & Low \\
\hline 2. & C5 & 22.94 & 20.98 & 21.76 & 23.15 & 23.80 & 25.28 & 24.61 & 22.41 & 23.24 & 22.84 & 23.10 & Low \\
\hline 3. & C6 & 31.17 & 28.82 & 29.44 & 31.11 & 31.67 & 31.11 & 31.18 & 28.89 & 28.82 & 27.65 & 29.99 & Low \\
\hline \multicolumn{10}{c}{ Total Score } \\
\hline
\end{tabular}

The students' HOTS in plant tissues were in the low category with a mean score of 26.12, where the analyze aspect (C4) scored 25.26 with the low category, the evaluate aspect (C5) scored 23.10 with the low category, and the create aspect (C6) scored 29.99 with the low category as presented in Fig. 1 .

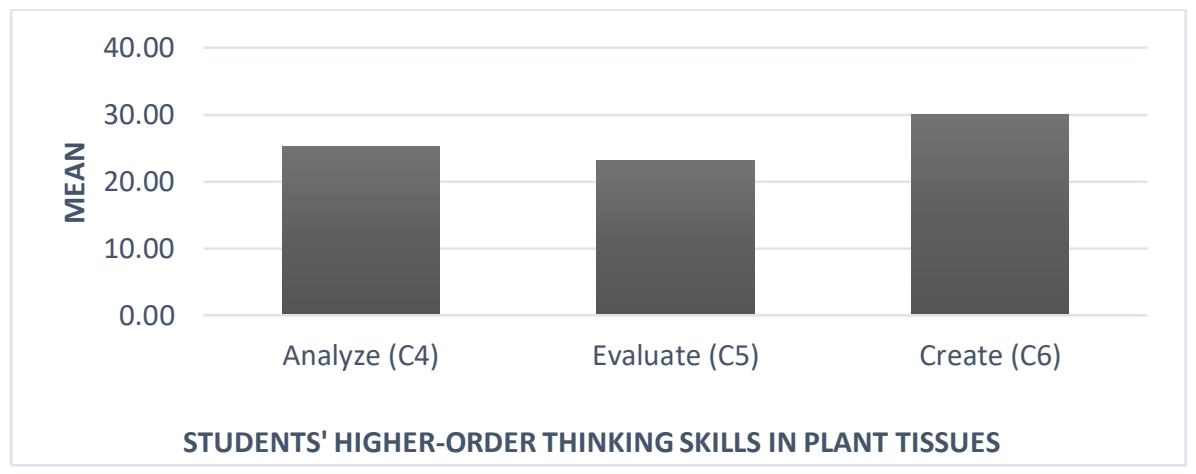

Fig.1. Results of students' higher-order thinking skills in plant tissues.

It could be clearly seen from the figure aforementioned that the three aspects of students' HOTS in plant tissues obtained the highest mean score of 29.99 on the create aspect (C6) and the lowest mean score of 23.10 on the evaluate aspect (C5). 
3.1.2 Results of Students' HOTS on the Topic of Human Locomotor System. From the results of students' HOTS in human locomotor system during the Covid-19 pandemic at SMA Negeri 4 Medan, the data recapitulation as presented in Table 2.

Table 2 . Students' HOTS on the topic of human locomotor system.

\begin{tabular}{cccccccccccccc}
\hline No. & Aspect & XI-1 & XI-2 & XI-3 & XI-4 & XI-5 & XI-6 & XI-7 & XI-8 & XI-9 & XI-10 & Mean & Category \\
\hline 1. & C4 & 31.50 & 30.90 & 30.55 & 29.70 & 31.15 & 30.30 & 29.45 & 31.95 & 29.70 & 30.25 & 30.55 & Low \\
\hline 2. & C5 & 30.24 & 29.24 & 30.44 & 30.32 & 19.78 & 27.90 & 28.48 & 26.02 & 26.12 & 26.02 & 27.46 & Low \\
\hline 3. & C6 & 31.37 & 28.80 & 30.17 & 30.57 & 29.80 & 28.90 & 29.60 & 25.93 & 27.07 & 26.44 & 28.87 & Low \\
\hline \multicolumn{10}{c}{ Total Score } \\
\hline
\end{tabular}

The students' HOTS in human locomotor system were in the low category with a mean score of 28.96, where the analyze aspect (C4) scored 30.55 with the low category, the evaluate aspect (C5) scored 27.46 with the low category, and the create aspect (C6) scored 28.87 with the low category as presented in Fig. 2.

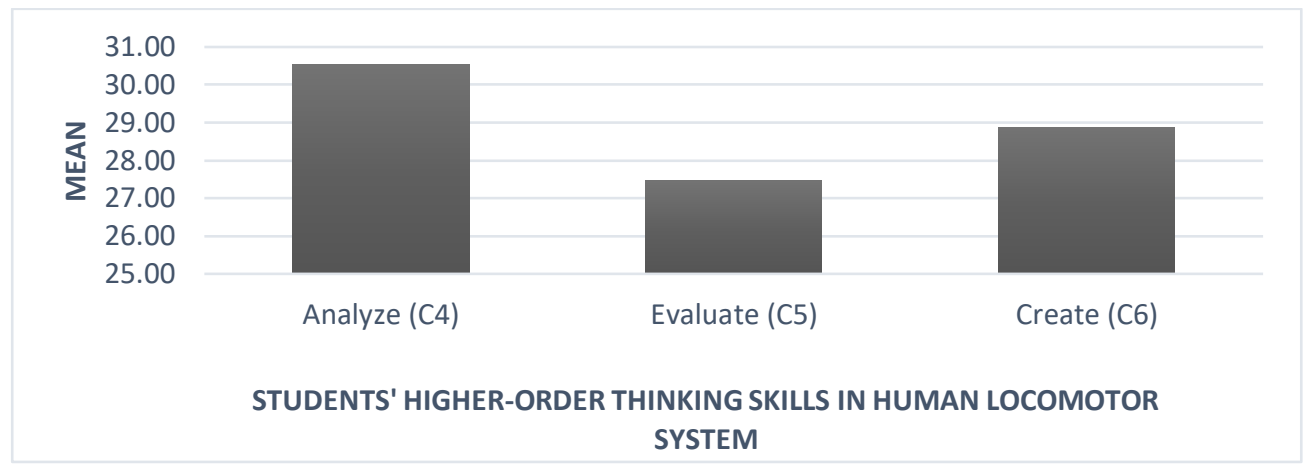

Fig. 2. Results of students' higher-order thinking skills in human locomotor system.

3.1.3 Results of Students' HOTS on the Topic of Human Circulatory System. From the results of students' HOTS in human circulatory system during the Covid-19 pandemic at SMA Negeri 4 Medan, the data recapitulation as presented in Table 3.

Table 3. Students' HOTS on the topic of human circulatory system.

\begin{tabular}{cccccccccccccc}
\hline No. & Aspect & XI-1 & XI-2 & XI-3 & XI-4 & XI-5 & XI-6 & XI-7 & XI-8 & XI-9 & XI-10 & Mean & Category \\
\hline 1. & C4 & 23.53 & 25.49 & 26.30 & 27.04 & 26.67 & 27.78 & 28.24 & 27.59 & 26.47 & 25.69 & 26.48 & Low \\
\hline 2. & C5 & 28.71 & 28.59 & 28.56 & 28.78 & 28.33 & 27.94 & 28.24 & 27.11 & 26.59 & 26.62 & 27.94 & Low \\
\hline 3. & C6 & 23.24 & 25.00 & 25.28 & 26.11 & 26.11 & 26.67 & 26.76 & 25.83 & 25.59 & 20.88 & 25.15 & Low \\
\hline \multicolumn{10}{c}{ Total Score } \\
\hline
\end{tabular}


The students' HOTS in human circulatory system were in the low category with a mean score of 26.52, where the analyze aspect (C4) scored 26.48 with the low category, the evaluate aspect (C5) scored 27.94 with the low category, and the create aspect (C6) scored 25.15 with the low category as presented in Fig. 3

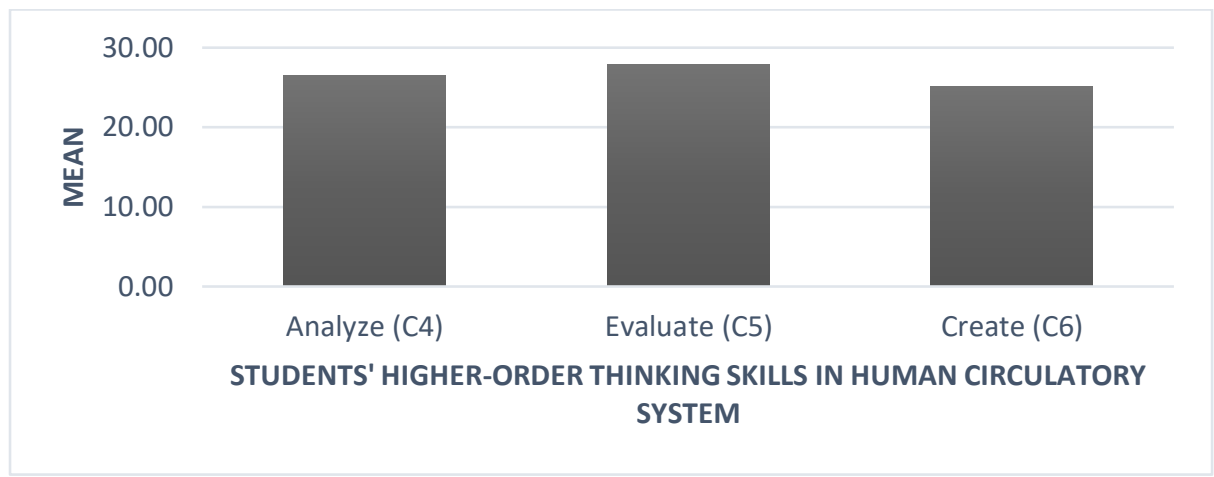

Fig. 3. Results of students' higher-order thinking skills in human circulatory system.

It could be obviously seen from the figure aforementioned that the three aspects of students' HOTS in human locomotor system obtained the highest mean score of 27.94 on the evaluate aspect (C5) and the lowest mean score of 26.48 on the analyze aspect (C4).

\subsection{Students' Learning Processes during Covid-19 Pandemic}

From the results of students' learning processes during Covid-19 at SMA Negeri 4 Medan, the data recapitulation as presented in Table 4.

Table 4. Students' learning processes during Covid-19 at SMA Negeri 4 Medan.

\begin{tabular}{|c|c|c|c|c|c|c|c|c|c|c|c|c|c|}
\hline No. & Aspect & XI-1 & XI-2 & XI-3 & XI-4 & XI-5 & XI-6 & XI-7 & XI-8 & XI-9 & XI-10 & Mean & Category \\
\hline 1. & $\begin{array}{l}\text { Attitude } \\
\text { towards } \\
\text { online } \\
\text { learning }\end{array}$ & 28.24 & 25.39 & 26.11 & 27.31 & 27.31 & 26.67 & 26.86 & 27.87 & 24.61 & 26.96 & 26.73 & Poor \\
\hline 2. & $\begin{array}{l}\text { Using } \\
\text { internet } \\
\text { and } \\
\text { applicati } \\
\text { ons }\end{array}$ & 25.96 & 24.26 & 19.35 & 20.63 & 22.78 & 22.36 & 23.33 & 21.81 & 24.41 & 25.29 & 23.02 & Poor \\
\hline 3. & $\begin{array}{l}\text { Using } \\
\text { digital } \\
\text { devices }\end{array}$ & 25.69 & 28.63 & 24.26 & 30.74 & 36.94 & 30.19 & 29.41 & 30.00 & 24.31 & 29.22 & 28.94 & Poor \\
\hline 4. & Learnin & 22.16 & 21.37 & 19.81 & 20.37 & 19.44 & 20.37 & 22.16 & 20.00 & 19.80 & 22.94 & 20.84 & Poor \\
\hline
\end{tabular}


The students' learning processes during Covid-19 were in the unfavorable category with a mean score of 33.18, where the aspect of attitude towards online learning scored 26.73 with the poor category, the aspect of using internet and applications scored 23.02 with the poor category, the aspect of using digital devices scored 28.94 with the poor category, and the aspect of learning media and materials during online learning scored 20.84 with the poor category as presented in Fig. 4.

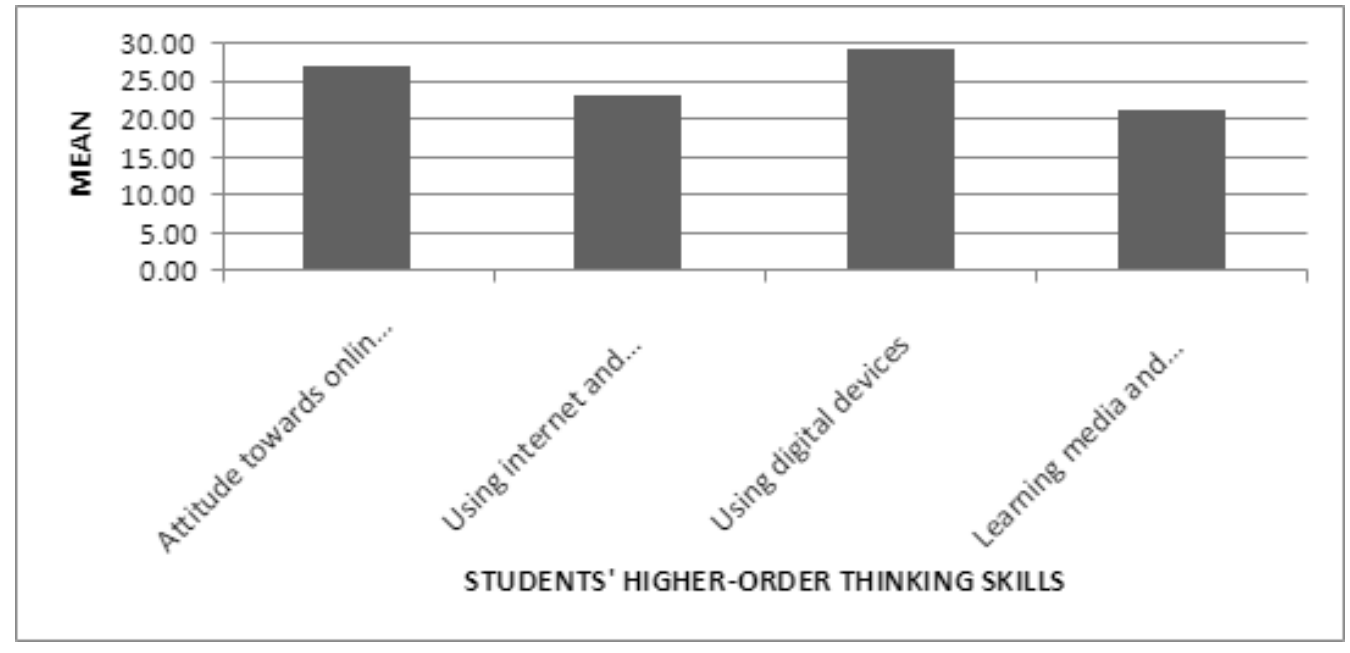

Fig. 4. Results of students' learning processes during Covid-19 at SMA Negeri 4 Medan.

It could be clearly seen from the figure aforementioned that the four aspects of students' learning processes during Covid-19 pandemic obtained the highest mean score of 28.94 on the aspect of using digital devices and the lowest mean score of 20.84 on the aspect of learning media and materials during online learning.

\subsection{Students' Higher-Order Thinking Skills (HOTS)}

The students' HOTS in plant tissues were in the low category scored 26.12, students' HOTS in human locomotor system were in the low category scored 28.96, and students' HOTS in human circulatory system were in the low category scored 26.52. Meanwhile the mean aspect of students' HOTS scored 27.2 in the low category. This is because students are less 
trained in solving contextual problems, demanding reasoning, argumentation and creativity in solving them. Therefore, students' HOTS are obtained on a low average during the Covid-19 pandemic. In accordance with the following research results.

Hussen, et al [6] found that the students' HOTS in schools was still very low, which was indicated by the low level of reasoning of students in solving HOTS questions. Fanani [7] explained that one of the contributing factors was because students were not trained in solving contextual problems, demanding reasoning, argumentation and creativity in solving them. According to Hidayati [8], it was not easy for teachers to create and train students to think critically. Therefore, the expected solution will not be easy to find if you do not know the source of the problem at hand. One of the ways used to see where the problems faced by students in practicing their higher order thinking skills is by looking at the misconceptions that occur when solving HOTS questions. This mismatch of understanding can also be an error in the application of a rule or an inaccurate generalization.

Rezky \& Edi [9] explained that misconceptions of previous knowledge would hinder the acquisition process of understanding new concepts and cause students to continue to make mistakes during learning. Aminah et al [10] explained that the right learning model could have an influence on higher-order thinking skills. According to Sahara et al [11] explained that media such as textbooks had a good effect on students' higher order thinking. Learning by using the steps of the scientific method provides a learning experience for students to be able to interact with biological objects directly.

\subsection{Students' Learning Processes During Covid-19}

The students' learning processes during Covid-19 pandemic were in the poor category scored 33.18. The use and mastery of internet applications is a very important ability when learning online systems today, this is in accordance with the recent study of Dimyati et al., [12] that online learning media built using applications provide features that can accommodate online learning needs. Some of the features provided include: assignments, exams, communication, collaboration, and the main feature that can upload various formats of learning materials.

Furthermore, the findings of Mauly's [13] that the use of online applications is more varied, not only through using the Whatsapp and Zoom applications which are already commonly used. So students and teachers can simultaneously learn new things to increase enthusiasm and not feel bored quickly when carrying out online learning. Apart from the explanation above, Sadikin and Hamidah [14] explained that the facilities and infrastructure for carrying out online learning. Online learning is effective for overcoming learning that allows educators to interact in virtual classrooms that can be accessed anywhere and anytime.

Learning media is very important to help students understand biology learning with an online system, as explained by Talakua and Elly [15] that has shown that there is an effect of using mobile learning-based learning media on students' interest in learning and creative thinking abilities. Related to the results of this study, it is recommended for high school biology teachers to use mobile learning-based learning media more often in classroom learning because through this learning students gain meaningful practical experience so that interest in learning and students' creative thinking skills can be improved. 


\section{Conclusion}

Based on the results regarding the analysis of students' higher-order thinking skills during the Covid-19 pandemic at SMA Negeri 4 Medan, it can be concluded that students' higherorder thinking skills on the topics of Biology (Plant Tissues, Human Locomotor and Circulatory Systems) during the Covid-19 pandemic scored 27.2 in the low category. The students' learning processes during the Covid-19 pandemic scored 33.18 in the poor category.

\section{References}

[1] Imaniah K., Bariah. Design of Development of Online-Based Learning Assessment Instruments. Journal of Science and Technology. 2019; 5(1): 31-47.

[2] Gikas J, Grant M. Mobile Computing Devices in Higher Education: Student Perspectives on Learning with Cellphones, Smartphones \& Social Media. Internet and Higher Education; 2013.

[3] Hasruddin, Harahap F, Mahmud. Preparation of Instruments for Science Process Skills Based on Contextual Inquiry in Microbiology Lectures. Proceedings of Biology Education Conference. 2018; 15(1):627-634.

[4] Hasrudin. Maximizing Critical Thinking Ability Through Contextual Approach. Journal of Tabularasa PPS UNIMED. 2009; 6(1): 48-60.

[5] Ahmad S. Learning and Learning Theory. Jakarta: Kencana Prenada Media Group; 2014.

[6] Hussen S, As'ari A.R, Chandra TD. Analysis of Student Posing Problems Judging from Bloom's Taxonomy. Journal of the Study of Mathematics Learning. 2017; 1(2): 119 - 126.

[7] Fanani MZ. Strategy for Development of Higher Order Thinking Skills (HOTS) in Curriculum 2013. Edudeena Journal of Islamic Religious Education. 2018; 2(1): 57-76.

[8] Hidayati AU. Training Higher Order Thinking Skills in Mathematics Learning in Elementary School Students. Journal of Basic Education and Learning. 2017; 4(2): 143-156.

[9] Rezky AH, Edi TMS. Analysis of Errors and Misconceptions of Class VIII Students on Algebraic Materials. Educentric, Journal of Education and Teaching Science. 2014; 1(2): 18-26.

[10] Aminah W, Hasruddin, Diningrat DS. The Influence of Inquiry and Advance Organizer Learning Models on Higher-Level Thinking Skills on Respiratory System Material at MAN Rantauprapat. Proceedings of the Third National Seminar on Biology and Learning, State University of Medan: 2017; 846-859.

[11] Sahara KR, Hasruddin, Hasairin A. The Influence of Microbiology Dictionary and Microbiology Textbook Utilization in the Contextual Learning Framework on Biology Students Higher Order Thinking Skills. Proceedings of The 3rd Annual International Seminar on Transformative Education and Educational Leadership (AISTEEL); 2018.

[12] Dimyati M. Study and Learning. Jakarta: Rineka Cipta; 2002. 
[13] Mauly YK. Online Learning Method Using Online Application During the Covid-19 Pandemic Period at Az-Zahra Sragen. Islamic Religious Education Study Program, Faculty of Islamic Religion. University of Muhammadiyah Surakarta; 2020.

[14] Sadikin A, Hamidah A. Online Learning in the Midst of the Covid-19 Outbreak. BIODIK: Scientific Journal of Biology Education. 2020; 6 (02): 214-224.

[15] Talakua C, Elly SS. Effect of the used of Biology Learning Media Based on Mobile Learning on Learning Interest and Creative Thinking Ability of High School Students in Masohi City. Biodik: Scientific Journal of Biology Education. 2020; 6(1): 46-57. 